\title{
Record of Retained Body Fluids or Tissue Sample
}

National Cancer Institute

\section{Source}

National Cancer Institute. Record of Retained Body Fluids or Tissue Sample. NCI

Thesaurus. Code C115570.

Documentation pertaining to identification and location information of samples being held for possible future (re) testing. 